\title{
Solvent-free $\mathrm{N}$-alkylation of amides with alcohols catalyzed by nickel on silica-alumina
}

\begin{abstract}
Aubin Charvieux, ${ }^{[a]}$ Louis Le Moigne, ${ }^{[a]}$ Lorenzo G.
Abstract: The $\mathrm{N}$-alkylation of phenylacetamide with benzyl alcohol has been studied using $\mathrm{Ni} / \mathrm{SiO}_{2}-\mathrm{Al}_{2} \mathrm{O}_{3}$. In the optimized conditions, the desired product was isolated in an excellent $98 \%$ yield. The reaction could advantageously be performed in neat conditions, with a slight excess of amide and a catalytic amount of base. These conditions were tested on a large range of amides and alcohols, affording 24 compounds in 13 to $99 \%$ isolated yields.
\end{abstract}

The formation of an amide $\mathrm{C}-\mathrm{N}$ bond is one of the key processes for the synthesis of peptides, pharmaceuticals, polymers and natural products. ${ }^{[1-4]}$ Amides are generally synthesized by condensation of carboxylic acids (or their esters, anhydrides or acyl chloride analogs) with amines, or by the reaction between an amide and an aryl or aliphatic halide. ${ }^{[5-9]}$ However, those methods exhibit a poor atom economy, as they inevitably lead to the formation of stoichiometric amounts of waste. Though less explored than the previously cited methods, reductive alkylation of amides with aldehydes has been reported by our group as a greener alternative, ${ }^{[10]}$ along with other nitrogen nucleophiles. ${ }^{[11,12]}$ A high hydrogen pressure is however required, and aldehydes generally need to be purified before use as they easily oxidize. The borrowing hydrogen methodology solves these issues, as it uses alcohols both as alkylating agents and hydrogen sources. ${ }^{[13-}$ 15] The $\mathrm{N}$-alkylation of amides with alcohols has been firstly reported in the pioneer work of Watanabe et al. with $\mathrm{RuCl}_{2}\left(\mathrm{PPh}_{3}\right)_{3}{ }^{[16]}$ Shortly after, Jenner improved the yields and the scope of this reaction by including secondary alcohols with $\mathrm{RuCl}_{2}\left(\mathrm{PBu}_{3}\right)_{3}$ as a catalyst. ${ }^{[17]}$ More recently, $\left[\mathrm{Ru}(p \text {-cymene }) \mathrm{Cl}_{2}\right]_{2}$ with DPEphos has been reported under microwave activation. ${ }^{[18]}$ The $\mathrm{N}$-alkylation of amides with alcohols has been mainly explored with homogeneous Ir catalysts, such as $\left[\mathrm{Cp}^{*} \mid \mathrm{ICl}_{2}\right]_{2}$ (1 to $5 \mathrm{~mol} \%$, at $\left.130-160^{\circ} \mathrm{C}\right) .{ }^{[19-21]}$ The loading of the catalyst and the reaction temperature could be reduced by using a $\mathrm{N}$-Heterocyclic Carbene - phosphine ligand ${ }^{[22]}$ or a benzoxazolyl ligand, ${ }^{[23]}$ thus improving the activity of the Ir catalyst. This reaction has been also reported with homogeneous $\mathrm{Pd}$, using $\mathrm{Pd}(\mathrm{OAc})_{2}{ }^{[24,25]}$ or a heterobimetallic $\mathrm{Pd}-\mathrm{Sn}$ catalyst ${ }^{[26]}$, and $\mathrm{Rh}$, with the Wilkinson catalyst. ${ }^{[27,28]}$ Only two examples of homogeneous non-noble metal complexes were reported, with $\mathrm{Cu}(\mathrm{OAc})_{2}{ }^{[29]}$ and a $\mathrm{NiBr}_{2} /$ phenanthroline catalytic system. ${ }^{[30]}$ Whereas some of these catalytic system require toxic solvents such as toluene or o-xylene,

[a] Univ Lyon, Université Claude Bernard Lyon1, CNRS, INSA-Lyon, CPE-Lyon, Institut de Chimie et Biochimie Moléculaires et Supramoléculaires, ICBMS, UMR 5246, Equipe CAtalyse, SYnthèse et ENvironnement (CASYEN), Campus LyonTech La Doua, Bâtiment Lederer, 1 rue Victor Grignard, 69100 Villeurbanne, France

E-mail: nicolas.duguet@univ-lyon1.fr estelle.metay@univ-lyon1.f

Supporting information for this article is given via a link at the end of the document.((Please delete this text if not appropriate)) a significant part of the previously cited examples does not require an additional solvent. However, in these cases, a large excess of alcohol (from 3 to 6 equivalent) is used. Few heterogeneous catalysts were used for the $\mathrm{N}$-alkylation of amide with alcohols. An Ag/Mo oxide $\left(\mathrm{Ag}_{6} \mathrm{Mo}_{10} \mathrm{O}_{33}\right)$ was used by Shi et al. ${ }^{[31]}$ However, the authors did not report any recyclability test for their catalyst. Kobayashi et al. reported an example of recyclable catalyst for this reaction, with polymer-incarcerated $\mathrm{Au} / \mathrm{Pd}$ nanoparticles with carbon black as a secondary support, and $\mathrm{Ba}(\mathrm{OTf})_{2}$ as an additive. ${ }^{[32]}$ To this date, no non-noble metal based heterogeneous has been reported for this reaction. Our group has been investigating the efficiency of $\mathrm{Ni} / \mathrm{SiO}_{2}-\mathrm{Al}_{2} \mathrm{O}_{3}$ for the $\alpha$ alkylation of ketones with alcohols, including methanol. ${ }^{[3,34]}$ Furthermore, this catalyst has been fully characterized.(See ESI) Herein, we report our new findings on the catalytic activity of $\mathrm{Ni} / \mathrm{SiO}_{2}-\mathrm{Al}_{2} \mathrm{O}_{3}$ for the solvent-free $\mathrm{N}$-alkylation of amides with alcohols.

The $\mathrm{N}$-alkylation of phenylacetamide 1a with benzyl alcohol 2a has been chosen as the model reaction for the initial investigation, leading to the formation of the desired product: $\mathrm{N}$ benzyl-2-phenylacetamide 3a. During this optimization, benzyl 2phenylacetate $\mathbf{4}$ was identified as the major by-product. The formation of the ester $\mathbf{4}$ is probably consequent to the nucleophilic addition of $\mathbf{2 a}$ on $\mathbf{1 a}$, thus releasing ammonia. A range of bases was first tested, with a 2 to 1 ratio of amide $\mathbf{1 a}$ to alcohol $\mathbf{2 a}, 20$ $\mathrm{mol} \%$ of $65 \mathrm{wt} \% \mathrm{Ni} / \mathrm{SiO}_{2}-\mathrm{Al}_{2} \mathrm{O}_{3}$ and $10 \mathrm{~mol} \%$ of base. The reaction mixture was heated at $175^{\circ} \mathrm{C}$ for $15 \mathrm{~h}$, without added solvent (Table 1). AcOK, a weak base, allowed to obtain $3 \mathbf{a}$ in $60 \%$ GC

Table 1. Base screening for the $N$-alkylation of phenylacetamide 1a with benzyl alcohol 2 a catalyzed by $\mathrm{Ni} / \mathrm{SiO}_{2}-\mathrm{Al}_{2} \mathrm{O}_{3}{ }^{[\mathrm{a}]}$

\begin{tabular}{|c|c|c|c|c|}
\hline$\underbrace{O}_{1 a}$ & $\widehat{2 a}_{\mathrm{Ph}}^{\mathrm{Ni} / \mathrm{SiO}}$ & $\begin{array}{l}\frac{3}{3}(20 \mathrm{~mol} \%) \\
\stackrel{\mathrm{mol} \%)}{\longrightarrow} \mathrm{Ph}\end{array}$ & & \\
\hline Entry & Base $(\mathrm{mol} \%)$ & GC conv. ${ }^{[b]}$ & $3 \mathbf{a}^{[\mathrm{c}]}$ & $4^{[c]}$ \\
\hline 1 & AcOK & 81 & 60 & 17 \\
\hline 2 & ${ }^{t} \mathrm{BuOK}$ & 97 & 90 & 2 \\
\hline 3 & $\mathrm{KOH}$ & 97 & 90 & 3 \\
\hline 4 & $\mathrm{~K}_{3} \mathrm{PO}_{4}$ & 96 & 93 & 1 \\
\hline 5 & $\mathrm{Cs}_{2} \mathrm{CO}_{3}$ & 87 & 82 & 4 \\
\hline 6 & $\mathrm{Na}_{2} \mathrm{CO}_{3}$ & $>99$ & 95 & $<1$ \\
\hline 7 & $\mathrm{~K}_{2} \mathrm{CO}_{3}$ & 96 & 95 & $<1$ \\
\hline
\end{tabular}

[a] Reaction conditions: 1a (19.32 mmol, 2 eq.), 2a (9.67 mmol, 1 eq.), $65 \mathrm{wt} \% \mathrm{Ni} / \mathrm{SiO}_{2}-\mathrm{Al}_{2} \mathrm{O}_{3}(20 \mathrm{~mol} \%)$, base $(10 \mathrm{~mol} \%)$, neat, $175^{\circ} \mathrm{C}, 15 \mathrm{~h}$. [b] GC conversion of $\mathbf{2 a}$. [c] $\mathrm{GC}$ ratio. 
ratio, with moderate selectivity as the ester 4 was formed in 17\% GC ratio (Table 1, Entry 1). Reaction with stronger bases such as ${ }^{t} \mathrm{BuOK}$ and $\mathrm{KOH}$ lead to good results, with $90 \%$ ratio and high conversion (Table 1, Entries 2 and 3 ). $\mathrm{K}_{3} \mathrm{PO}_{4}$, used in our previous work, allowed the formation of $\mathbf{3 a}$ in a $93 \%$ ratio (Table 1, Entry 4). Some carbonates were then tested. $\mathrm{Cs}_{2} \mathrm{CO}_{3}$ afforded the product in $82 \%$ ratio while it was obtained in $95 \%$ ratio with $\mathrm{Na}_{2} \mathrm{CO}_{3}$ and $\mathrm{K}_{2} \mathrm{CO}_{3}$ (Table 1, Entries 5-7). The selectivity with $\mathrm{Na}_{2} \mathrm{CO}_{3}$ being slightly lower, $\mathrm{K}_{2} \mathrm{CO}_{3}$ was selected as the most suitable base for this reaction. Other parameters, such as nickel loading, $\mathbf{1 a} / \mathbf{2 a}$ ratio and reaction conditions were then studied (Table 2). In an effort of increasing the greenness of this reaction, the quantity of the nickel catalyst was decreased to $10 \mathrm{~mol} \% \mathrm{Ni}$. Advantageously, it did not highly impact the formation of the desired product $3 \mathbf{a}$, as it was observed in a $81 \%$ ratio (Table 2 , Entry 1). Further reduction of the quantity of nickel was not found suitable for the reaction. Ratio of $\mathbf{1 a} / \mathbf{2} \mathbf{a}$ was then decreased to 1.5 to 1 , allowing to observe $3 a$ in $92 \%$ ratio, with a $93 \%$ conversion of $\mathbf{2 a}$ (Table 2, Entry 2). Further decrease of this ratio to 1.2 to 1 impacted negatively the ratio of $\mathbf{3 a}(82 \%$, Table 2 , Entry 3$)$. The conversion could be increased to $99 \%$ by increasing the time to $20 \mathrm{~h}$, thus affording the desired $\mathrm{N}$-benzylated amide $\mathbf{3 a}$ in an excellent $98 \%$ isolated yield (Table 2, Entry 4 ). Decreasing the temperature to $160^{\circ} \mathrm{C}$ highly impacted the kinetics of the reaction, as conversion of $\mathbf{2 a}$ was only $47 \%$ (Table 2, Entry 5). Blank experiments were then performed. As expected, the desired product was not formed when the reaction was run without nickel catalyst (Table 2, Entry 6). Small amounts of product were formed in the absence of base (Table 2, Entry 7). Interestingly, ester 4 was the major product in this case. The formation of the benzaldehyde intermediate by dehydrogenation of $2 a$ is most probably reversible. In the absence of base, the kinetics of the

Table 2. Conditions screening for the $\mathrm{N}$-alkylation of phenylacetamide 1a with benzyl alcohol 2 a catalyzed by $\mathrm{Ni} / \mathrm{SiO}_{2}-\mathrm{Al}_{2} \mathrm{O}_{3}{ }^{[a]}$

\begin{tabular}{|c|c|c|c|c|}
\hline$\stackrel{1}{1}_{\mathrm{NH}_{3}}^{\mathrm{O}}$ & h $\begin{array}{r}\mathrm{Ni} / \mathrm{SiO}_{2}-\mathrm{Al}_{2} \\
\mathrm{~K}_{2} \mathrm{CO}_{3} \\
\text { neat, } 175\end{array}$ & $\begin{array}{l}0 \mathrm{~mol} \%) \\
\underset{15 \mathrm{~h}}{\mathrm{nol} \%)}\end{array}$ & & \\
\hline Entry ${ }^{[a]}$ & $1 a / 2 a$ ratio & GC conv. ${ }^{[b]}$ & $3 \mathbf{a}^{[c]}$ & $4^{[c]}$ \\
\hline 1 & $2: 1$ & 86 & 81 & $<1$ \\
\hline 2 & $1.5: 1$ & 93 & 92 & $<1$ \\
\hline 3 & $1.2: 1$ & 87 & 82 & 1 \\
\hline $4^{d}$ & $1.5: 1$ & 99 & $99(98)$ & $<1$ \\
\hline $5^{\dagger}$ & $1.5: 1$ & 47 & 42 & 5 \\
\hline $6^{g}$ & $2: 1$ & 2 & 0 & 1 \\
\hline $7^{\mathrm{h}}$ & $2: 1$ & 59 & 19 & 31 \\
\hline
\end{tabular}

[a] Reaction conditions: 1a (19.32 mmol, 2 eq.), 2a (9.67 mmol, 1 eq.), $65 \mathrm{wt} \% \mathrm{Ni} / \mathrm{SiO}_{2}-\mathrm{Al}_{2} \mathrm{O}_{3}(10 \mathrm{~mol} \%), \mathrm{K}_{2} \mathrm{CO}_{3}(10 \mathrm{~mol} \%)$, neat, $175^{\circ} \mathrm{C}, 15 \mathrm{~h}$. [b] GC conversion of 2a. [c] GC ratio. [d] $20 \mathrm{~h}$. [e] Isolated yield. [f] $160^{\circ} \mathrm{C}$. [g] Ni: 0 $\mathrm{mol} \%$. [h] $\mathrm{K}_{2} \mathrm{CO}_{3}: 0$ mol\%. condensation of $\mathbf{1 a}$ on $\mathbf{2} \mathbf{a}$ is likely to be decreased, as the base is thought to catalyze this step and could also play a role in the dehydrogenation of $\mathbf{2 a}$. Consequently, from a macroscopic point of view, more benzyl alcohol $\mathbf{2 a}$ is probably available, thus increasing the rate of the nucleophilic addition of $\mathbf{2} \mathbf{a}$ on $\mathbf{1 a}$, leading to the formation of the corresponding ester. This ester could also be formed by the insertion of nickel in the $\mathrm{C}-\mathrm{N}$ bond of $\mathbf{1 a}$, as reported by Garg et al. ${ }^{[35,36]}$ New investigations would be required in order to confirm the capacity of $\mathrm{Ni} / \mathrm{SiO}_{2}-\mathrm{Al}_{2} \mathrm{O}_{3}$ to perform this insertion.

Other products were also observed in low amount during this optimization study, such as benzylamine $\mathbf{5}$, dibenzylamine $\mathbf{6}$, tribenzylamine 7 and $N, N$-dibenzyl-2-phenylacetamide 8 . The formation pathways of these products was studied. As previously mentioned, the formation of the ester 4 could produce ammonia as a coproduct. This reactive compound could be benzylated by benzyl alcohol through a borrowing hydrogen mechanism, as reported in the literature, thus leading to the formation of benzylamine. ${ }^{[37-40]}$ This primary amine was successfully alkylated by benzyl alcohol in the optimized conditions, affording dibenzylamine (54\% GC ratio) and $N$-benzylidene-1phenylmethanamine (46\% GC ratio) (Scheme 1, A). Dibenzylamine could be converted into tribenzylamine (2\% GC ratio) with benzyl alcohol in the same conditions (Scheme 1, B). These three amines could therefore be formed by consecutive borrowing hydrogen processes. $\mathrm{N}, \mathrm{N}$-dibenzyl-2-phenylacetamide 8 could a priori be produced by direct benzylation of the desired product 3a. However, $\mathbf{8}$ was not observed when $\mathbf{3 a}$ and benzyl alcohol were submitted to the optimized conditions. Interestingly, this product could be observed in a $25 \%$ GC ratio by reaction between dibenzylamine and the ester 4 in alkaline conditions $\left(\mathrm{K}_{2} \mathrm{CO}_{3}, 10 \mathrm{~mol} \%\right)$ at $175^{\circ} \mathrm{C}$ during $20 \mathrm{~h}$ (Scheme 1, C). After some optimization, this product was isolated in $24 \%$ yield. (Scheme 1, D) In the same manner, the desired product 3a could

$$
\begin{aligned}
& \text { A) } \quad \mathrm{Ni}^{2} / \mathrm{SiO}_{2}-\mathrm{Al}_{2} \mathrm{O}_{3}(10 \mathrm{~mol} \%)
\end{aligned}
$$

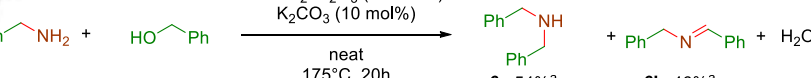

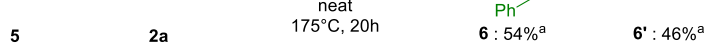

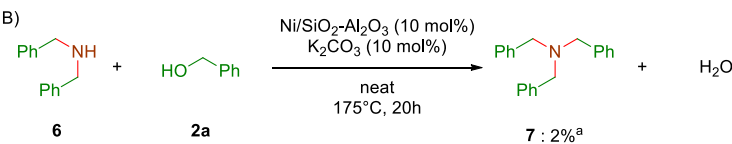

$$
\begin{aligned}
& \text { C) }
\end{aligned}
$$

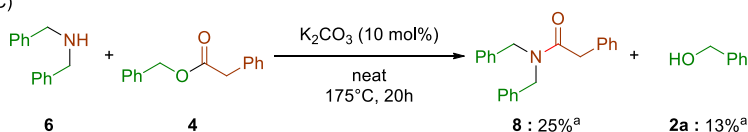

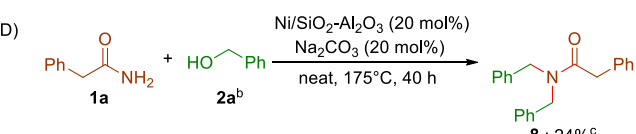

$$
\begin{aligned}
& \text { E) } \\
& 5 \quad 4 \quad 175^{\circ} \mathrm{C}, 20 \mathrm{~h} \quad 3 \mathrm{a}: 79 \%^{\mathrm{d}} \quad 2 \mathrm{a}: 79 \%^{\mathrm{d}}
\end{aligned}
$$

Scheme 1. Study of the formation of the byproducts. Starting materials were introduced in equimolar quantities, unless otherwise specified. [a] GC ratio. [b] 5 equiv. [c] Isolated yield. See ESI for full procedure. [d] ${ }^{1} \mathrm{H}$ NMR ratio. 


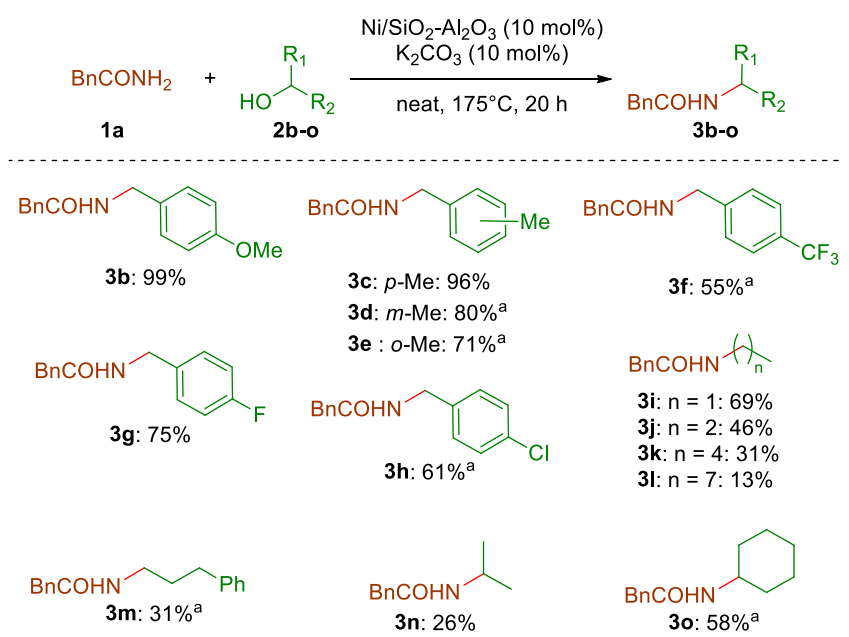

Figure 1. $\mathrm{N}$-alkylation of phenylacetamide with alcohols catalyzed by $\mathrm{Ni} / \mathrm{SiO}_{2}-$ $\mathrm{Al}_{2} \mathrm{O}_{3}$. Reaction conditions: 1a (19.32 mmol), 2b-o (12.88 mmol), $65 \mathrm{wt} \% \mathrm{Ni} / \mathrm{SiO}_{2}-\mathrm{Al}_{2} \mathrm{O}_{3}(10 \mathrm{~mol} \%), \mathrm{K}_{2} \mathrm{CO}_{3}(10 \mathrm{~mol} \%)$, neat, $175^{\circ} \mathrm{C}, 20 \mathrm{~h}$ unless otherwise specified. [a] $60 \mathrm{~h}$.

be formed by reaction between benzylamine and the ester 4 in $79 \%$ NMR ratio (Scheme 1, E). We have therefore demonstrated that di- $N$-alkylation of phenylacetamide could be performed indirectly through a borrowing hydrogen process. This reaction will be further investigated in next works.

A range of alcohols and amides was then tested to evaluate the versatility of the optimized conditions. Phenylacetamide 1a was first $\mathrm{N}$-alkylated by several alcohols (Figure 1). Some benzyl alcohols with electron-donating groups were first tested. Excellent yields were obtained with $p$-methoxy and $p$-methylbenzyl alcohols (3b and 3c resp., 99 and $96 \%$ yield). As expected a slight decrease of yield was noticed with $m$ - and $o$ methylbenzylalcohols (3d and $\mathbf{3 e}$ resp., 80 and $71 \%$ yield), which

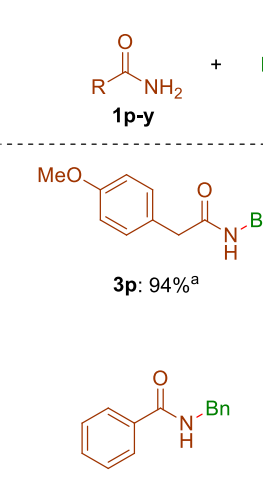

3u: $76 \%$
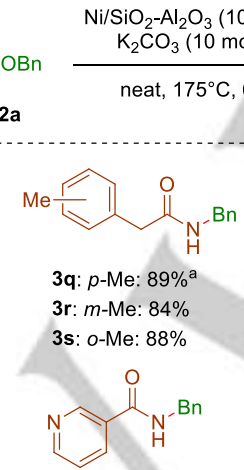

3v: $39 \%$
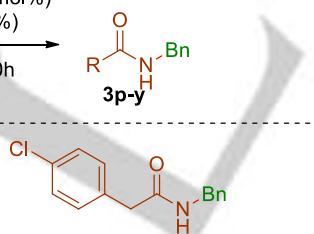

3t: $61 \%$

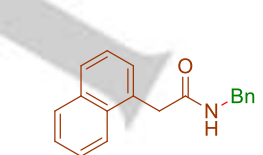

$3 \mathbf{w}: 60 \%$

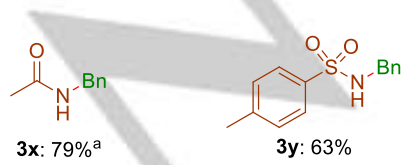

Figure 2. $\mathrm{N}$-alkylation of various amides with benzyl alcohol catalyzed by $\mathrm{Ni} / \mathrm{SiO}_{2}-\mathrm{Al}_{2} \mathrm{O}_{3}$. Reaction conditions: 1p-y (19.32 mmol), 2a (12.88 mmol), $65 \mathrm{wt} \% \mathrm{Ni} / \mathrm{SiO}_{2}-\mathrm{Al}_{2} \mathrm{O}_{3}(10 \mathrm{~mol} \%), \mathrm{K}_{2} \mathrm{CO}_{3}\left(10 \mathrm{~mol} \%\right.$ ), neat, $175^{\circ} \mathrm{C}, 60 \mathrm{~h}$ unless otherwise specified. [a] $20 \mathrm{~h}$.

could easily be explained by the increase of the steric hindrance induced by the methyl group. Benzyl alcohols bearing an electronwithdrawing group seemed less reactive, as a moderate 55\% yield was obtained with $p$-trifluoromethylbenzyl alcohol (3f). $p$ Fluoro and $p$-chlorobenzyl alcohols afforded the desired product in good yields ( $\mathbf{3 g}$ and $\mathbf{3 h}$ resp., 75 and $61 \%$ yield). For $p$ chlorobenzyl alcohol, the dechlorinated product 3a was observed in low amounts. Surprisingly, the desired reaction did not occur with p-bromobenzyl alcohol and p-bromobenzyl phenylacetate was obtained as the main product, in low amounts. The $N$ alkylation of 1a with a range of aliphatic alcohols was also investigated. Linear alcohols, such as ethanol, 1-propanol, 1pentanol and 1-octanol gave good to low yields (3i, 3j, 3k, $\mathbf{3}$ r resp., $69,46,31,13 \%$ yield). It was observed that the yield of the desired products decreased and that the amount of ester increased when the chain length increased. This could partially be explained by the increase of nucleophilicity of linear alcohols with the increase of the chain length. The reaction 3-phenylpropan-1-ol afforded the desired product $3 \mathrm{~m}$ in a low $31 \%$ yield while the ester was observed in high quantity. 2-Propanol and cyclohexanol gave the desired products in low and moderate yield (3n and $\mathbf{3 0}$ resp., 26 and $58 \%$ yield).

A range of amides was also $\mathrm{N}$-alkylated with benzyl alcohol in the optimized conditions (Scheme 2). Phenylacetamides bearing electron-withdrawing substituents on the aromatic ring gave high to excellent yields. The reaction using 4methoxyphenylacetamide gave the desired product $3 p$ in an excellent $94 \%$ yield. Para-, meta-, and ortho-phenylacetamides gave the desired product in very good yields $(89 \%, 84 \%$ and $88 \%$ for $\mathbf{3 q}, \mathbf{3 r}$ and $3 \mathrm{~s}$ resp.). A good $61 \%$ yield was obtained with parachlorophenylacetamide. Interestingly, dechlorination of the starting material or the desired product was negligible. A good yield was obtained with benzamide $(3 \mathbf{u}, 76 \%)$, while $N$ benzylnicotinamide was formed in moderate yield $(\mathbf{3 v}, 39 \%) .1$ naphtylacetamide gave the desired product $3 \mathbf{w}$ in a moderate $60 \%$ yield. A good result was obtained with acetamide, affording the desired product $\mathbf{3 x}$ in $79 \%$ yield. A sulfonamide, paratolylsulfonamide was engaged in reaction with benzyl alcohol in the optimized conditions to afford the desired $\mathrm{N}$-benzylated product in a good yield $(3 \mathbf{y}, 60 \%)$.

The recyclability of the $\mathrm{Ni}$ catalyst was studied with the model reaction over 5 runs (Figure 3 ). The reactions were performed in $6 \mathrm{~h}$, at incomplete conversion, in order to detect efficiently a potential loss of catalytic activity. After each run, the crude mixture was filtered on Millipore paper $(1 \mu \mathrm{m})$ and the catalyst was washed with acetone and water, dried and reengaged into reaction. The mass of the recycled catalyst was measured each time and the quantities of the other components of the reaction were recalculated accordingly. During this study, the desired product was virtually obtained as the sole product, as its GC selectivity was always greater than $98 \%$. After 6 hours of reaction, GC ratio of $3 a$ was $54 \%$ after the first run. Surprisingly, this ratio increased until run \#3, reaching $82 \%$. The ratio then decreases rapidly (run\# 5: 41\%). The catalyst seems first to undergo an activation, then a deactivation. It is noteworthy that the mass of the catalyst after each run decreases quickly, from $115 \mathrm{mg}$ (run\# 1) to $66 \mathrm{mg}$ (run\# 5). Interestingly, $11 \mathrm{mg}$ of nickel 


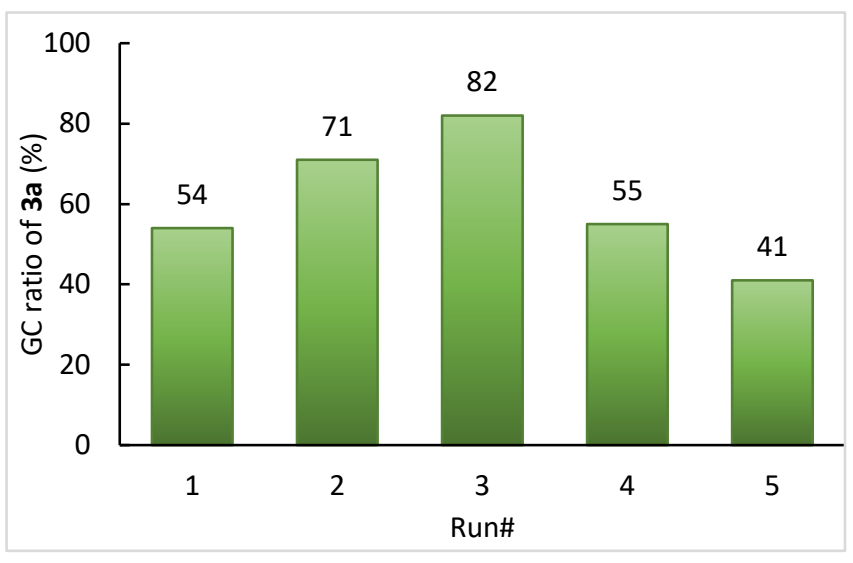

Figure 3. Recycling study of the nickel catalyst for the $\mathrm{N}$-alkylation of phenylacetamide with benzyl alcohol.

were detected in the solution obtained by hot filtration after $6 \mathrm{~h}$ of reaction. This value corresponds to a loss of $14.7 \%$ of the initial mass, highlighting a leaching of the catalyst into solution. The actual nickel loading on the catalyst support probably decreases in the course of the different runs due to this leaching. Further studies will be undertaken in order to establish the cause of these observations.

In conclusion, we performed the first $\mathrm{N}$-alkylation of amides with alcohols promoted by a non-noble heterogeneous catalyst: nickel on silica-alumina. The reaction conditions were optimized with benzyl alcohol and phenylacetamide as model substrates. The desired product was isolated in an excellent $98 \%$ yield, with a slight excess of phenylacetamide (1.5 eq.), $10 \mathrm{~mol} \%$ of $\mathrm{Ni} / \mathrm{SiO}_{2-}$ $\mathrm{Al}_{2} \mathrm{O}_{3}$ and $\mathrm{K}_{2} \mathrm{CO}_{3}$ in $20 \mathrm{~h}$ at $175^{\circ} \mathrm{C}$ without any solvent. The study of the reaction pathways leading to the reaction byproducts was performed. The scope of the reaction was investigated with a range of amides and alcohols, affording $24 \mathrm{~N}$-alkylated amides in 13 to $99 \%$ isolated yield.

\section{Acknowledgements}

The authors thank the Ministère de l'Enseignement Supérieur, de la Recherche et de l'Innovation (MESRI) for a Ph.D. grant to A. C.

Keywords: $N$-alkylation $•$ amides $•$ alcohols $\bullet$ nickel $•$ heterogeneous catalysis

[1] D. G. Brown, J. Boström, J. Med. Chem. 2016, 59, 4443-4458.

[2] J. M. Humphrey, A. R. Chamberlin, Chem. Rev. 1997, 97, 2243-2266.
[3] A. El-Faham, F. Albericio, Chem. Rev. 2011, 111, 6557-6602.

[4] J. R. Dunetz, J. Magano, G. A. Weisenburger, Org. Process Res. Dev. 2016, 20, 140-177.

[5] C. L. Allen, J. M. J. Williams, Chem. Soc. Rev. 2011, 40, 3405-3415.

[6] C. A. G. N. Montalbetti, V. Falque, Tetrahedron 2005, 61, 1082710852.

[7] R. M. de Figueiredo, J.-S. Suppo, J.-M. Campagne, Chem. Rev. 2016 116, 12029-12122.

[8] R. M. Lanigan, T. D. Sheppard, Eur. J. Org. Chem. 2013, 2013, 74537465.

[9] A. Ojeda-Porras, D. Gamba-Sánchez, J. Org. Chem. 2016, 81 , $11548-11555$

[10] F. Fache, L. Jacquot, M. Lemaire, Tetrahedron Lett. 1994, 35, 33133314.

[11] F. Fache, F. Valot, A. Milenkovic, M. Lemaire, Tetrahedron 1996, 52, 9777-9784.

[12] T. M. E. Dine, S. Chapron, M.-C. Duclos, N. Duguet, F. Popowycz, M. Lemaire, Eur. J. Org. Chem. 2013, 2013, 5445-5454.

[13] A. Corma, J. Navas, M. J. Sabater, Chem. Rev. 2018, 118, 14101459.

[14] Y. Obora, Top. Curr. Chem. 2016, 374, 11

[15] G. Guillena, D. J. Ramón, M. Yus, Chem. Rev. 2010, 110, 1611-1641.

[16] Y. Watanabe, T. Ohta, Y. Tsuji, Bull. Chem. Soc. Jpn. 1983, 56, 2647-2651.

[17] G. Jenner, J. Mol. Catal. 1989, 55, 241-246.

[18] A. J. A. Watson, A. C. Maxwell, J. M. J. Williams, J. Org. Chem. 2011 76, 2328-2331.

[19] T. D. Apsunde, M. L. Trudell, Synthesis 2014, 46, 230-234.

[20] K. Fujita, A. Komatsubara, R. Yamaguchi, Tetrahedron 2009, 65, 3624-3628.

[21] F. Li, P. Qu, J. Ma, X. Zou, C. Sun, ChemCatChem 2013, 5, 21782182.

[22] S. Kerdphon, X. Quan, V. S. Parihar, P. G. Andersson, J. Org. Chem. 2015, 80, 11529-11537.

[23] S. Huang, S.-P. Wu, Q. Zhou, H.-Z. Cui, X. Hong, Y.-J. Lin, X.-F. Hou J. Organomet. Chem. 2018, 868, 14-23.

[24] A. Martínez-Asencio, M. Yus, D. J. Ramón, Synthesis 2011, 2011, 3730-3740.

[25] X. Yu, L. Jiang, Q. Li, Y. Xie, Q. Xu, Chin. J. Chem. 2012, 30, 23222332.

[26] A. Mohanty, S. Roy, Tetrahedron Lett. 2016, 57, 2749-2753.

[27] S. L. Feng, C. Z. Liu, Q. Li, X. C. Yu, Q. Xu, Chin. Chem. Lett. 2011 22, 1021-1024.

[28] C. Liu, S. Liao, Q. Li, S. Feng, Q. Sun, X. Yu, Q. Xu, J. Org. Chem. 2011, 76, 5759-5773.

[29] A. Martínez-Asencio, D. J. Ramón, M. Yus, Tetrahedron 2011, 67, 3140-3149.

[30] J. Das, D. Banerjee, J. Org. Chem. 2018, 83, 3378-3384

[31] X. Cui, Y. Zhang, F. Shi, Y. Deng, Chem. - Eur. J. 2011, 17, 10211028.

[32] G. C. Y. Choo, H. Miyamura, S. Kobayashi, Chem. Sci. 2015, 6 1719-1727.

[33] A. Charvieux, J. B. Giorgi, N. Duguet, E. Métay, Green Chem. 2018 , 20, 4210-4216.

[34] A. Charvieux, N. Duguet, E. Métay, Eur. J. Org. Chem. 2019, 2019, 3694-3698.

[35] L. Hie, E. L. Baker, S. M. Anthony, J.-N. Desrosiers, C. Senanayake, N. K. Garg, Angew. Chem. Int. Ed. 2016, 55, 15129-15132.

[36] L. Hie, N. F. Fine Nathel, T. K. Shah, E. L. Baker, X. Hong, Y.-F. Yang, P. Liu, K. N. Houk, N. K. Garg, Nature 2015, 524, 79-83.

[37] S. Imm, S. Bähn, L. Neubert, H. Neumann, M. Beller, Angew. Chem. Int. Ed. 2010, 49, 8126-8129.

[38] D. Ruiz, A. Aho, T. Saloranta, K. Eränen, J. Wärnå, R. Leino, D. Yu. Murzin, Chem. Eng. J. 2017, 307, 739-749.

[39] C. Gunanathan, D. Milstein, Angew. Chem. Int. Ed. 2008, 47, 86618664 .

[40] W. Baumann, A. Spannenberg, J. Pfeffer, T. Haas, A. Köckritz, A. Martin, J. Deutsch, Chem. - Eur. J. 2013, 19, 17702-17706. 
Entry for the Table of Contents (Please choose one layout)

Layout 1:

\section{COMMUNICATION}

Text for Table of Contents

Layout 2:

\section{COMMUNICATION}

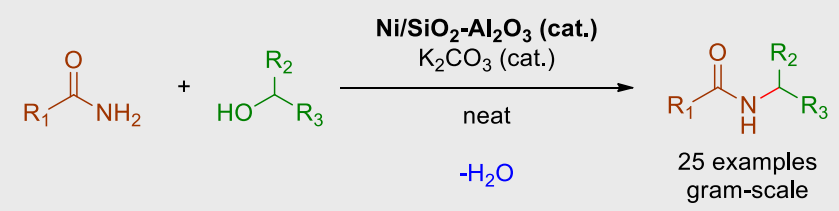

To date, the $\mathrm{N}$-alkylation of amides with alcohols has not been studied with non-noble metal base heterogeneous catalyst. Herein, we report that a range of amide could be efficiently $\mathrm{N}$-alkylated with various alcohols using cheap and easy to handle $\mathrm{Ni} / \mathrm{SiO}_{2}$ $\mathrm{Al}_{2} \mathrm{O}_{3}$.
Author(s), Corresponding Author(s)*

\section{Page No. - Page No.}

Title

\section{((Insert TOC Graphic here))}

Aubin Charvieux, Louis Le Moigne, Nicolas Duguet, ${ }^{*}$ Estelle Métay ${ }^{*}$

Page No. - Page No.

Solvent-free $\mathrm{N}$-alkylation of amides with alcohols catalyzed by nickel on silica-alumina 